\title{
Variations in Physiological Metabolites and Chlorophyll in Sexual Phenotypes of 'Rincon' Fourwing Saltbush
}

\author{
ARTHUR R. TIEDEMANN, E. DURANT MCARTHUR, AND D. CARL FREEMAN
}

\begin{abstract}
An experiment was conducted to determine if concentrations of chlorophyll and basic metabolites (total organic nitrogen (TN), total phosphorus (TP), and total nonstructural carbohydrates (TNC)) were an indication of the physiological vigor of the 3 sexual phenotypes of fourwing saltbush (Atriplex canescens (Pursh) Nutt.). Our basic hypothesis was that males, females, and plants capable of male and female sex expression (sexually labile) were equally vigorous as was manifested in chlorophyll and metabolite levels. In June, concentrations of chlorophyll a, b, and total chlorophyll in the male phenotype were greater than in either the female or the labile phenotypes. There were no differences among phenotypes for the other dates. Male plants had the highest levels of metabolites (TN, TP, and TNC) when any differences among sexual phenotypes were significant. There were basically no differences in metabolite concentration between the female and labile sexual phenotypes. Results indicate that part of the hypothesis should be rejected-that male, female, and sexually labile plants are equally vigorous based on concentrations of chlorophyll and metabolites. Part of the hypothesis, however, can be acceptedthat females and labile plants are comparable in physiological vigor. Levels of all 3 metabolites showed striking trends among sample dates, which indicated that fourwing saltbush has the capability of rebuilding its levels of metabolites in the spring at the physiologically costly time of flowering. This may be related to the photosynthetic efinciency associated with its C-4 photosynthetic pathway.
\end{abstract}

Key Words: Atriplex canescens, nutrition, plant physiology, nutrient elements (plants), range plants, seasonal variations

\footnotetext{
Authors are principal range scientist, Pacific Northwest Research Station, La Grande, Ore. 97850; supervisory research geneticist, Intermountain Research Station, Provo, Utah 84601; and associate professor, Department of Biological Sciences, Wayne State University, Detroit, Mich. $\mathbf{4 8 2 0 2}$.

This work was facilitated by National Science Grant DEB-81-11010 and by the Pittman Robertson Wildlife Habitat Project W82R. The Snow Field Station is cooperatively maintained by the USDA Forest Service, Intermountain Research Station; Utah State Division of Wildlife Resources, Utah State Agricultural Experiment Station; and Snow College. Authors wish to thank Kathy Brinkerhoff, Diane McCune, and Carlos Lopez for excellent technical assistance.

Manuscript accepted 8 September 1986.
}

Fourwing saltbush (Atriplex canescens (Pursh) Nutt.) is a subdioecious chenopod shrub species consisting of males, females, and plants capable of male and female sexual expression (sexually labile) depending on environmental conditions (McArthur 1977, McArthur and Freeman 1982). McArthur and Freeman (1982) have proposed a model that suggests a relatively constant male to female percentage in a given population with an additional proportion that is labile and capable of male or female expression. The sexually labile portion of the population tends toward femaleness when temperatures and moisture are favorable. When conditions are not favorable and the plants are under stress of drought or extreme temperatures, the labile portion switches to predominant maleness. This suggests that it may be more costly in terms of resources for a plant to reproduce as a female than it is to be a male in stressful times. The vigor of the individual sexual phenotypes very likely plays a major role in their ability to withstand environmental stress. Male plants have been shown to live longer than female plants (Freeman et al. 1984). If sexual expression is a function of individual plant vigor, it should be reflected in components that are the product of or that affect the basic physiology of the plant such as chlorophyll and metabolites. There is precedence in the literature for such a hypothesis. Wallace and Rundel (1979) found that male jojoba (Simmondsia chinensis (Link) Schneid) plants maintain higher levels of nitrogen $(N)$ and phosphorus $(P)$ in their leaves than do female plants in the same population. Percent total allocation of $\mathbf{N}$ and $\mathbf{P}$ was also greater in males than in females. Willson and Ruppel (1984) present data showing that more mineral nutrient resources are allocated to female floral components than to male for several grass species.

The hypothesis we are testing is: that males, females, and labile plants of fourwing saltbush are of equal physiological vigor as manifested in levels of chlorophyll and physiological metabolites. The hypothesis consists of 3 parts or comparisons: male plants = female plants; male plants = labile plants; female plants = labile plants. In addition to testing the basic hypothesis, another objective was to evaluate trends in chlorophyll and metabolites across a variety of sample dates. This enables us to determine if the relation- 
ship among sexual phenotypes is the same among seasons (and phenological stages). Also, by measuring physiological metabolites across a variety of sample dates, we can relate seasonal accumulation and depletion patterns to phenologic events.

\section{Methods}

To test our hypothesis, we evaluated 4 important plant components: chlorophyll, total nonstructural carbohydrates (TNC), total organic nitrogen (TN), and total phosphorus (TP) in the 3 sexual phenotypes as a function of season. These components were chosen because they represent measurable end-products of several of the plant's basic physiological processes. Chlorophyll is an expression of the ability of the plant to utilize solar energy for carbon fixation. Total nitrogen, although not specifically a reflection of the individual amino acids, proteins, and amines in the plant, does represent an integrated view of the efficiency with which plants synthesize proteins. Total nonstructural carbohydrates are an expression of the ability of the plant to fix and store starches and sugars and are dependent on season and time of sampling. These compounds are used for respiration by the plant and may be a direct reflection of the physiologial vigor of the plant. Total phosphorus was measured because it is intricately tied to the energy transformation within the plant via adenosine diphosphatetriphosphate.

To reduce the variability associated with slope position, aspect, soil variations, competition, and other uncontrolled features of a wildland setting, we conducted this study in a uniform garden at Snow Field Station (see acknowledgements), Ephraim, Utah. The 3 sexual phenotypes were studied in this garden for 13 years (1972-1984). The plants of the cultivar Rincon fourwing saltbush (McArthur et al. 1984) were planted at random in the garden in a spacing of $1.3 \mathrm{~m} \times 1.3 \mathrm{~m}$.

Chlorophyll content (chlorophyll a, b, and total) was determined for 10 plants of each sexual phenotype on 22 June, $20 \mathrm{July}$, and 22 August 1982. The same plants were sampled each time. Four interior and 4 exterior leaves were sampled for each plant. Leaves were packed in dry ice and transported to the Shrub Sciences Laboratory, Intermountain Research Station, in Provo for analysis. A $10-\mathrm{mm}$ disc of leaf tissue was removed from each leaf and weighed. The chlorophyll of each disc was extracted with DMSO by use of Hough's (personal communication) modification of Burnison's (1980) method. Extraction was initiated within 3 hours of sample collection. Concentrations of chlorophyll $a$ and $b$ were determined spectrophotometrically by use of Lorenzen's (1967) equations. Results are expressed in milligrams of chlorophyll per gram of leaf tissue.

To evaluate the variation in metabolites, TNC, TN, and TP among sexual phenotypes and sample dates, we sampled leaves and current year stems of 15 randomly selected plants of each sexual phenotype on 6 dates beginning in July 1981 and ending in August 1982. Because of the severe effects of winter on some plants (December 1981 to February 1982), the same plants could not be sampled each time. We substituted plants that were randomly selected as alternates at the start of the study. Samples were packed in dry ice and transported to the Shrub Sciences Laboratory within 3 hours of collection. As soon as they reached the laboratory, the samples were heated by microwave to stop enzymatic activity and to preserve the integrity of carbohydrates and nitrogenous compounds. Microwave treatment is comparable to the conventional autoclave treatment for preparing tissue for analyses of TNC and TN (Tiedemann et al. 1984). After leaves and stems were heated by microwave, they were oven-dried at $70^{\circ} \mathrm{C}$ until constant weight was reached, usually 48 hours. Leaves and stems were separated and ground to 60-mesh fineness.

Samples were analyzed for TNC by digestion with takadiastase enzyme (daSilveira et al. 1978), followed by colorimetric determination of the concentration of the resultant sugar residues with Teles' reagent (Teles et al. 1978). Total organic $\mathbf{N}$ was analyzed by macro-
Kjeldahl digestion followed by titrimetric determination of $\mathrm{NH}_{4}-\mathrm{N}$ (Black et al. 1965). Total $\mathrm{P}$ was by $\mathrm{H}_{2} \mathrm{SO}_{4}$, selenium digestion (Parkinson and Allen 1975) followed by molybedenum blue determination of $P$. Results were referenced to standard plant materials from the National Bureau of Standards analyzed along with our samples.

For the chlorophyll data, split-plot design analysis of variance was used to analyze differences among the sexual phenotypes (main effect) and between interior and exterior exposures (splitplot effect) for each sample date. Results for metabolites TNC, TN, and TP were analyzed statistically using a two-way analysis of variance with sample dates and sexual phenotypes as main effects in a completely random design (Steel and Torrie 1960). The least significant difference (LSD) test (Carmer and Swanson 1971) was used for comparisons of means where the F-test was significant.

\section{Results and Discussion}

The F-test for differences in chlorophyll concentration was significant $(P<0.01$ ) for sexual phenotypes only in June; the LSD test showed that all 3 chlorophyll components were significantly $(P<0.05)$ higher in the male phenotype than in the other 2 phenotypes (Table 1), which suggested a higher level of physiological

Table 1. Concentrations of chlorophyll $a, b$, and total chlorophyll in three sexual phenotypes of Atriplex canescens on three sample dates in 1982.

\begin{tabular}{|c|c|c|c|}
\hline $\begin{array}{l}\text { Component and } \\
\text { date }\end{array}$ & Female & Male & Labile \\
\hline & 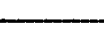 & $\mathrm{mg} / \mathrm{g}$ & - \\
\hline $\begin{array}{l}\text { Chlorophyll a: } \\
\text { June } 22^{1} \\
\text { July } 20^{2} \\
\text { August } 22^{2}\end{array}$ & $\begin{array}{l}0.052 \mathrm{a} \\
0.053 \\
0.031\end{array}$ & $\begin{array}{l}0.063 b \\
0.055 \\
0.031\end{array}$ & $\begin{array}{l}0.051 \mathrm{a} \\
0.055 \\
0.030\end{array}$ \\
\hline $\begin{array}{l}\text { Chlorophyll b: } \\
\text { June } 22^{1} \\
\text { July } 20^{2} \\
\text { August } 22^{2}\end{array}$ & $\begin{array}{l}0.010 \mathrm{a} \\
0.013 \\
0.008\end{array}$ & $\begin{array}{l}0.012 b \\
0.013 \\
0.009\end{array}$ & $\begin{array}{l}0.008 a \\
0.014 \\
0.009\end{array}$ \\
\hline $\begin{array}{l}\text { Total chlorophyll } \\
\text { June } 22^{1} \\
\text { July } 20^{2} \\
\text { August } 22^{2}\end{array}$ & $\begin{array}{l}0.062 a \\
0.066 \\
0.039\end{array}$ & $\begin{array}{l}0.075 b \\
0.068 \\
0.039\end{array}$ & $\begin{array}{l}0.059 a \\
0.068 \\
0.039\end{array}$ \\
\hline
\end{tabular}

IValues followed by the same letter within an individual date are not significant at $P<0.05$.

${ }^{2}$ No LSD test was conducted for July and August because the F-test was not significant for sexual phenotype.

vigor for the male plants. It appears that male plants are inherently predisposed to greater levels of physiological vigor in June than are female or labile plants. The latter 2 appear to start at a disadvantage. We were unable to statistically analyze differences among dates because variances were not homogeneous. There was, however, a tendency for striking reductions in all 3 chlorophyll components between the first 2 sample dates and the August sample date for all 3 phenotypes. Higher levels in June and July correspond with floral initiation and early stages of seed formation. By August, the seed is full size (although not ripe). Seed is not ready to disperse until October. An exception was the trend in chlorophyll b in the labile phenotype-concentration was substantially higher in July than in June or August.

Position of leaf (exposure) exerted a significant $(P<0.05)$ effect on chlorophyll concentration on June and July sample dates (Table 2). In June, concentrations of all 3 components (average of sexual phenotypes) were significantly $(P<0.05)$ greater in the interior locations than in the exterior ones. In July, the interior leaves had significantly $(P<0.05)$ higher concentrations of chlorophyll $b$ and total chlorophyll than did the exterior leaves. There were no significant differences on the August date for leaf exposure. Interior leaves appear to be compensating for the reduction in light that occurs near the center of the plant in the early summer with higher 
Table 2. Effect of leaf exposure on chlorophyll concentrations in Atriplex canescens in 1982.1

\begin{tabular}{lccc}
\hline \hline Date and exposure & Chlorophyll a & Chlorophyll b & Total chlorophyll \\
\hline & & & \\
June 22: & $0.058 \mathrm{a}$ & $0.011 \mathrm{a}$ & $0.068 \mathrm{a}$ \\
$\quad$ Interior & $0.052 \mathrm{~b}$ & $0.009 \mathrm{~b}$ & $0.061 \mathrm{~b}$ \\
Exterior & & & \\
July 20: & $0.054 \mathrm{a}$ & $0.014 \mathrm{a}$ & $0.068 \mathrm{a}$ \\
$\quad$ Interior & $0.052 \mathrm{a}$ & $0.012 \mathrm{~b}$ & $0.065 \mathrm{~b}$ \\
Exterior & & & \\
August 22: & $0.030 \mathrm{a}$ & $0.009 \mathrm{a}$ & $0.038 \mathrm{a}$ \\
Interior & $0.031 \mathrm{a}$ & $0.008 \mathrm{a}$ & $0.039 \mathrm{a}$ \\
Exteror &
\end{tabular}

'Differences between exposures within an individual date with the same letter are not significantly different at $P<0.05$.

levels of chlorophyll than in the exterior leaves. This result is in keeping with the general pattern of chlorophyll discussed by Salisbury and Ross (1969).

Since chlorophyll levels were higher in the spring in male plants than in female or labile plants, we should reject the idea that they are equally vigorous physiologically. Because chlorophyll levels were the same in females and labile plants on all dates, however, we accept the part of the hypothesis that the females and labile phenotype are equally vigorous.

Analysis of variance showed that variation in metabolite level was high significant $(P<0.001)$ for all constituents in both stems and leaves for sample dates (Table 3). Differences among sexual

Table 3. F-test significance for main effects and interaction by each metabolite in leaves and stems of Atriplex canescens.

\begin{tabular}{|c|c|c|c|c|c|c|}
\hline \multirow[b]{2}{*}{ Variable } & \multicolumn{2}{|c|}{ Total phosphorus } & \multicolumn{2}{|c|}{$\begin{array}{c}\text { Total } \\
\text { organic nitrogen }\end{array}$} & \multicolumn{2}{|c|}{$\begin{array}{l}\text { Total nonstructural } \\
\text { carbohydrates }\end{array}$} \\
\hline & Leaves & Stems & Leaves & Stems & Leaves & Stems \\
\hline $\begin{array}{l}\text { Date } \\
\text { Sex } \\
\text { DxS }\end{array}$ & $\begin{array}{l}0.001 \\
0.410 \\
0.860\end{array}$ & $\begin{array}{l}0.001 \\
0.002 \\
0.765\end{array}$ & $\begin{array}{l}0.001 \\
0.004 \\
0.20\end{array}$ & $\begin{array}{l}0.001 \\
0.001 \\
0.42\end{array}$ & $\begin{array}{l}0.001 \\
0.19 \\
0.41\end{array}$ & $\begin{array}{l}0.001 \\
0.016 \\
0.41\end{array}$ \\
\hline
\end{tabular}

phenotypes were significant ( $P<0.001$ to $P<0.016$ ) for TP in stems, TN in leaves and stems, and TNC in stems. Total $P$ in leaves and TNC in leaves did not differ among sexual phenotypes. The date by sexual phenotype interaction was not significant for any metabolite in stems or leaves, which indicated that the relationship among phenotypes was comparable among dates.

To test the basic hypothesis, we compared the sexual phenotypes for each metabolite for each sample date. There were no significant differences $(P<0.05)$ among sexual phenotypes for any metabolite constituent on any individual date. Comparisons of metabolites among the 3 sexual phenotypes for all sample dates averaged, however, show significant differences and enabled us to test our hypothesis.

The male phenotype contained a significantly higher $(P<0.05)$ level of TN in leaves and stems and TP in stems than did the female phenotype (Table 4). Total nonstructural carbohydrate and TP in leaves were the same among all 3 sexual phenotypes. Male plants maintained significantly higher $(P<0.05)$ levels of TNC in stems than the labile phenotype did, but levels were the same as in the female plants. Male plants also maintained significantly higher $(P<0.05)$ levels of all 3 metabolites in stems than did the labile phenotype. These results caused us to reject the part of our basic hypothesis that male and female plants are equally vigorous based on metabolite level. We also reject the part of our hypothesis that male and sexually labile plants are equally vigorous. Labile plants, however, contained the same level of every constituent in stems and leaves as the females, which suggested that we accept the part of
Table 4. Metabolite levels in leaves and stems of A triplex canescens sexual phenotypes averaged for the six sample dates.'

\begin{tabular}{lcll}
\hline \hline Metabolite & Female & Male & Labile \\
\hline & & Percent- & \\
\cline { 2 - 4 } Total organic nitrogen & & & \\
$\quad$ Leaves & $3.15 \mathrm{a}$ & $3.39 \mathrm{~b}$ & $3.27 \mathrm{ab}$ \\
Stems & $1.69 \mathrm{a}$ & $1.88 \mathrm{~b}$ & $1.73 \mathrm{a}$ \\
Total nonstructural carbohydrates: & & \\
$\quad$ Leaves & $7.83 \mathrm{a}$ & $8.41 \mathrm{a}$ & $8.74 \mathrm{a}$ \\
$\quad$ Stems & $5.69 \mathrm{ab}$ & $5.96 \mathrm{~b}$ & $5.55 \mathrm{a}$ \\
Total phosphorus: & & & \\
$\quad$ Leaves & $0.27 \mathrm{a}$ & $0.29 \mathrm{a}$ & $0.27 \mathrm{a}$ \\
Stems & $0.19 \mathrm{a}$ & $0.22 \mathrm{~b}$ & $0.19 \mathrm{a}$ \\
\hline
\end{tabular}

1 Metabolite concentrations with the same letter in the same row are not significantly different at $P<0.05$.

our hypothesis that females and sexually labile plants were equal in physiological vigor.

The most striking feature of the data is the variation in metabolite levels that occurred among sample dates (Fig. 1). As we anticipated, metabolite levels were always higher in leaves than in stems. The comparisons among dates for each metabolite in Figure 1 are the average of the 3 sexual phenotypes.

There were no significant differences $(P<0.05)$ in TNC in leaves during the first 3 sample dates of 1981 (Fig. 1). In the stems during the same period, TNC levels declined significantly $(P<0.05)$ on each successive sample date. By April 1982, TNC levels had declined significantly compared with previous sample dates in both stems and leaves. The rapid decline in TNC levels between November 1981 and April 1982 may have been a consequence of the abnormally severe winter of 1981-1982 (Richardson et al. 1982) and the initiation of new leaves. Although this species retains many of its leaves through the winter, new leaves begin to form in April. By 10 June 1982, TNC levels had increased by nearly twofold for leaves and threefold for stems. This was followed by a sharp decline by August 1982 to levels near the April sample date. This period of decline coincides with fruit development and maturation. By August, fruit is mature but does not ripen and cast until October. Trends in TNC among dates were different than we would have anticipated from the results of McConnell and Garrison (1966) with bitterbrush (Purshia tridentata (Pursh) DC). In their study, TNC levels declined through the flowering and seed set periods (spring and early summer) and then began to increase. In fourwing saltbush, it appears that there may be only one period of carbohydrate replenishment and that carbohydrate depletion occurs during the remainder of the year. We cannot verify this conclusion with the 1981 data as we did not initiate sampling early enough to capture the period of TNC accumulation. The decline in all chlorophyll components between July and August, however, would tend to support such a conclusion. The fact that stems followed the trends of leaves indicates that the stem is an active storage area for TNC. It is significant to note that TNC was increasing at a time when the plant was most actively involved in flowering (June)typically a time of TNC depletion in other plants. The period of fruit set (mid-October) was marked by an active decline in TNC levels, but the decline may not be related to this because the same trend occurred with the male and labile sexual phenotypes.

Total $\mathbf{N}$ in leaves declined through the first 3 sample dates in 1981 and the first sample date in 1982 (Fig. 1). Although there were significant fluctuations $(P<0.05)$ in TN in stems among the first 4 sample dates, levels on 1 April 1982 were the same as on 30 July 1981. This was followed by an increase in TN similar to that for TNC in both stems and leaves and was succeeded by a rapid decline to the August 1982 sample date. Our trends in TN appear comparable to those observed by Hickman (1975). He observed distinct increases in crude protein (TN $\times 6.25$; Cook et al. 1962) of big 

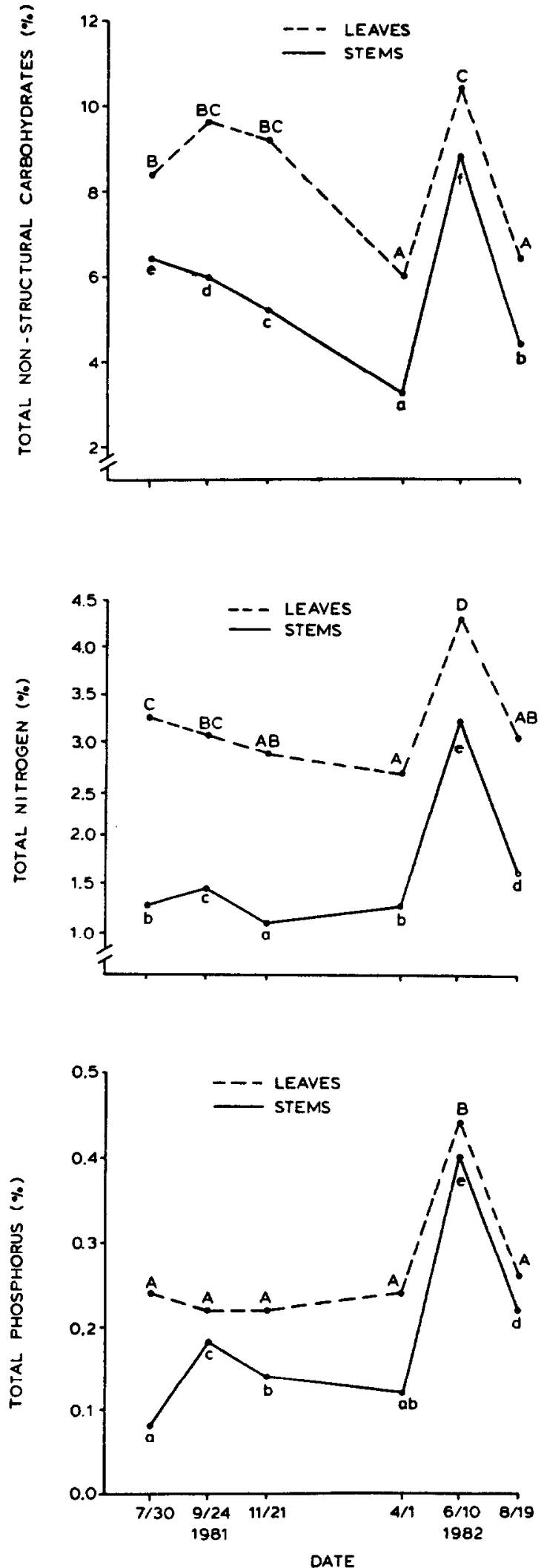

Fig. 1. Variations in total nonstructural carbohydrates, total organic nitrogen, and total phosphorus among sample dates in leaves and stems of Atriplex canescens. Values are average of the 3 sexual phenotypes. Values with the same letter are not significantly different at $\mathrm{P}<0.05$. Upper case letters designate comparison among dates for leaves-lower case for stems. sagebrush (Artemisia tridentata Nutt.), low sagebrush (Artemisia arbuscula Nutt.), curlleaf mountain mahogany (Cercocarpus ledifolius Nutt.), and bitterbrush during the late spring through early summer months in southeastern Oregon. Lowest levels occurred in the late fall and winter.

Trends in TP (Fig. 1) for 1982 were also similar to those reported by Hickman (1975): it increased during the late spring and early summer and declined in late summer and fall. The trends in 1981, however, were quite different from those noted by Hickman. Total $P$ levels in leaves of fourwing saltbush remained constant from 30 July through 1 April 1982. In the stems, TP increased by twofold between the July and September sample dates in 1981.

\section{Conclusions}

Chlorophyll and metabolite concentrations can be used as measures of the vigor of individual sexual phenotypes. The hypothesis that males and females are of equal physiological vigor was rejected in our comparisons among phenotypes of chlorophyll in June and average levels of TN in both leaves and stems and of TP in stems. Males had the highest values for metabolites and chlorophyll when values were significantly different. Higher levels of TN, $\mathrm{TP}$, and TNC in stems also indicate that the males are more vigorous than the labile plant group. Female and sexually labile plants were of comparable physiological vigor as was indicated by comparisons of metabolites and chlorophyll levels.

Higher levels of chlorophyll on the June sample date suggest that male plants may be inherently predisposed to contain higher concentrations of chlorophyll than are females or labile plants. The latter appear to start the growth season at a disadvantage.

From the standpoint of metabolite levels, there is no apparent advantage in the ability of the labile phenotype to control sexual dominance; however, this conclusion must be taken with caution because the metabolite levels that are observed may be either an intrinsic constant difference between the sexual phenotypes or the residual effect of the plants' having reproduced a posteriori. We did not measure reproduction during the period of study but, because of the unusually cold winter of 1981-82, would have expected a shift toward male dominance in the sexually labile group. If this occurred, it was not reflected in the metabolite levels which we speculate would have approximated those of the males.

The rapid increase in TNC, TN, and TP concentrations occurring at a stressful physiological time of flowering for fourwing saltbush can be speculated to be an adaptive feature resulting from its $\mathrm{C}-4$ photosynthetic pathway. This type of photosynthetic pathway occurs in fourwing saltbush (Downton 1975). Plants with this photosynthetic pathway appear to represent an advanced evolved state (Hatch et al. 1972), capable of prolonged low photosynthetic activity under conditions of high temperature and low soil moisture (Caldwell et al. 1977). Shadscale (Atriplex confertifiolia Torr. and Frem.), a related species with $\mathrm{C}-4$ photosynthesis, also possesses the ability to maintain maximum levels of photosynthesis at low temperatures and high levels of soil moisture associated with the early spring period (Caldwell et al. 1977). This may explain the rapid buildup of metabolite between April and June 1982 in all sexual phenotypes of fourwing saltbush.

\section{Literature Cited}

Black, C.A., D.D. Evans, J.L. White, et al. 1965. Methods of soil analysis. Part 2. Agron. No. 9, Amer. Soc. Agron., and Amer. Soc. Test. Mater. Madison, Wis.

Burnison, B.K. 1980. Modified dimethyl sulfoxide (DSMO) extraction for chlorophyll analysis of phytoplankton. Can. J. Fish and Aquatic Sci. 37:729-733.

Caldwell, M.M., R.S. White, R.T. Moore, and L.B. Camp. 1977. Carbon balance, productivity, and water use of cold winter desert shrub communities dominated by $\mathrm{C} 3$ and $\mathrm{C} 4$ species. Decologia (Berlin) 29:275300. 
Carmer, S.G., and M.R. Swanson. 1971. Detection of differences between means: a Monte Carlo study of five pairwise multiple comparison procedures. Agron. J. 63:940-945.

Cook, C.W., H.H. Biswell, R.T. Clart, et. al. 1962. Basic problems and techniques in range research. Pub. 890. Nat. Acad. Sci., Nat. Research Council, Washington, D.C.

dasilveria, A.J., F.F.F. Teles, and J.W. Stull. 1978. A rapid technique for total non-structurual carbohydrate determination of plant tissue. J. Agr. Food Chem. 26:770-772.

Downton, W.J.S. 1975. The occurrence of $\mathrm{C} 4$ photosynthesis among plants. Photosynthetica 9:96-105.

Freeman, D.C., E.D. McArthur, and K.T. Harper. 1984. The adaptive significance of sexual lability in plants using Atriplex canescens as a principal example. Ann. Missouri Bot. Gard. 71:251-263.

Hatch, M.D., C.B. Oumund, J.H. Troughton, and O. Bjorkman. 1972. Evolution of $\mathrm{C} 4$ photosynthesis. Carnegie Inst. Wash. Yearb. 71:135-141.

Hickman, O.E. 1975. Seasonal trends in the nutritive content of important range forage species near Silver Lake, Oregon. USDA Forest Serv. Res. Pap. PNW-187, 32 p. Pac. Northwest Forest and Range Exp. Sta., Portland, Ore.

Lorenzen, C.J. 1967. Determination of chlorophyll and phes-pigments: spectrophotometric equations. Limnol, and Oceanogr. 12:343-346.

McArthur, E.D. 1977. Environmentally induced changes in sex expression in Atriplex canescens. Heredity 38:97-105.

McArthur, E.D., and D.C. Freeman. 1982. Sex expression in atriplex canescens: genetics and environment. Bot. Gaz. 143:476-482.
McArthur, E.D., S.E. Stranathan, and G.L. Noller. 1984. 'Rincon' fourwing saltbush-proven for better forage and reclamation. Rangelands 6:62-64.

MeConneli, B.R., and G.A. Garrison. 1966. Seasonal variations of available carbohydrates in bitterbrush. J. Wildl. Manage. 30:168-172.

Parkineon, J.A., and S.E. Allen. 1975. A wet oxidation procedure suitable for the determination of nitrogen and mineral elements in biological material. Comm. Soil Sci. and Plant Anal. 6:1-11.

Richardson, E.A., G.L. Acheroft, and L.M. Cox. 1982. 1982 - the year the plug fell out. Utah Sci. 43:76-77.

Salisbury, F.B., and C. Ross. 1969. Plant physiology. Wadsworth, Belmont, Calif.

Steel, R.G.D., and J.H. Torrie. 1960. Principles and procedures of statistics. McGraw Hill Book Co., Inc.

Teles, F.F.F., C.K. Young, and J.W. Stull. 1978. A method for rapid determination of lactose. J. Dairy Sci. 61:506-508.

Tiedemann, A.R., E.D. McArthur, and C.F. Lopez. 1984. Carbohydrate and nitrogen contents in leaves of three shrub species following microwave, autoclave, and air-drying treatments. For. Sci. 30:113-116.

Wallace, C.S., and P.W. Rundel. 1979. Sexual dimorphism and resource allocation in male and female shrubs of Simmondsia chinensis. Oecologia (Berlin) 44:34-39.

Willeon, M.F., and K.P. Ruppel. 1984. Resource allocation and floral sex ratios in Zizania aquatica. Can. J. Bot. 62:799-805.

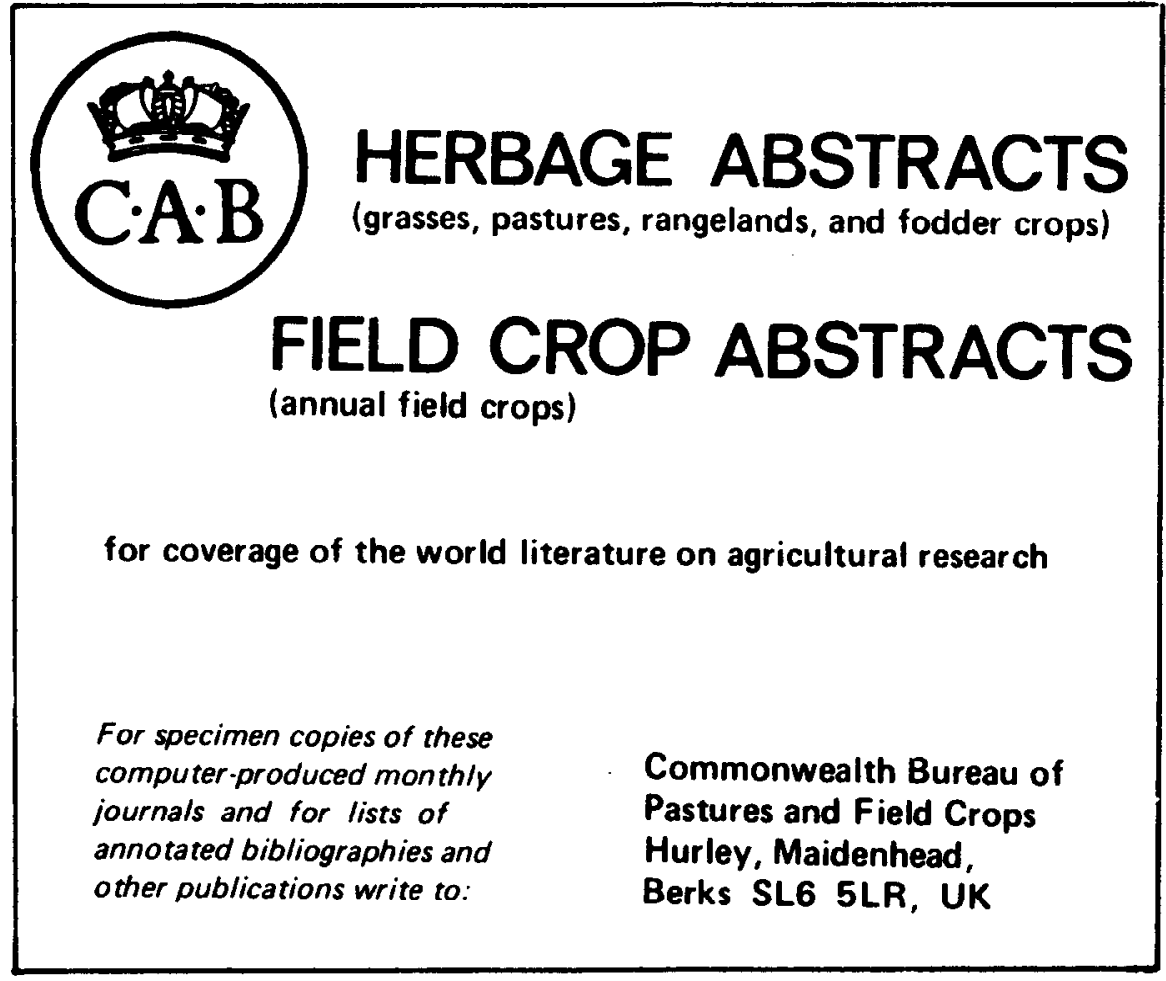

